DOI https://doi.org/10.36059/978-966-397-226-8-7

\title{
FEATURES OF THE APPLICATION OF CLIL-METHODIC FORMS IN THE STUDY OF HUMANITARIAN DISCIPLINES REMOTE TEACHING
}

\section{Yadlovska O. S.}

\section{INTRODUCTION}

Methods of content and language integrated learning in world pedagogical practice are called CLIL - Content and Language Integrated Learning and have begun to be used in the education system relatively recently, but the range of supporters of this technique is significantly expanding in many countries. The essence of these methods is the simultaneous use of a foreign language as an object of study, as well as mastering the content of other subjects, including disciplines of the humanities. In the processes of globalization of the world environment, CLIL-didactics becomes a promising area of higher education and an effective means of acquiring and improving speech and communication competencies. This will further ensure the successful professionalization and competitiveness of undergraduates in the labor market, as well as deepen ties in the immediate professional environment.

The main advantages of the method are the following characteristics: increasing the motivation to learn a foreign language, the development of creative abilities of the recipient, purposeful learning of lexical units. An important role in the practical application of the acquired communication skills will be played in the future by the fact that the proposed method promotes the use of interdisciplinary knowledge in practice and significantly expands the horizons of personality and communication and cultural competencies. Furthermore, the simultaneous purposeful mastery of the subject, language, and learning skills in a comfortable environment significantly improves the quality of communication and creates a situation of assistance. On the other hand, we emphasize the importance of implementing a layer of interdisciplinary knowledge in a foreign language in the processes of intercultural action and communication. In this section, not only the possession of a certain 
vocabulary plays an important role, but also the process of a kind of "immersion" in the cultural environment and understanding of the basic mental guidelines and guidelines of a particular ethnic group or cultural array. Such reflection is possible only through mastering the narrative of the humanities with the simultaneous study of a foreign language. We also emphasize that any communication actions between representatives of different states, peoples, ethnic groups involve a high level of cultural education and knowledge of a foreign language. This is the purpose of implementing CLIL methods as one of the possible ways to improve speech skills, on the one hand, and the acquisition of knowledge of the humanities, on the other, with the subsequent implementation in intercultural communication.

CLIL methodology is not absolutely innovative at this stage of educational development and in the process of applying various methods, because integrated learning has been implemented since the 80 s of the twentieth century. However, the trait of novelty lies in the plane of involvement of didactic material, modeling of training situations, use of tasks to be performed during remote teaching with the provision of probable maximum contact between the communicator and the recipient.

\section{Ambivalence of CLIL content and language integrated learning methodology and its involvement in the study of humanities disciplines}

At the present stage of reforming and qualitative changes in the educational paradigm, there are real opportunities to improve the training of undergradiares in learning foreign languages and the formation of a fully developed personality, ready to carry out foreign language communication, be a carrier of foreign culture, implement innovative processes in education. The implementation of such ambitious projects is the introduction of CLIL pedagogical technology into the educational process.

In the Ukrainian language, the abbreviation CLIL stands for content and language integrated learning (eng.- Content and Language 
Integrated Learning) ${ }^{147}$. In her works, O. M. Kochenkova argues that "CLIL is a didactic technique that allows undergraduates to form linguistic and communicative competences of a foreign language in the same educational context in which they are developing general knowledge and skills"148. L. G. Movchan considers the CLIL methodology as a context-language integrated learning ${ }^{149}$. At this stage, there are mainly three models of CLIL: soft (language-led), hard (subject-led), partial immersion. The first model aims to consider the linguistic features of the special context, the second means that $50 \%$ of the curriculum of specialty subjects are studied in a foreign language, and the third is intermediate and is used when only some modules of the specialty program are studied in a foreign language ${ }^{150}$.

CLIL training is based on the "adjunct / linked learning" methodology (integrated learning). The academic staff member whose function is connected with subject focuses his efforts and activities on the translation of content knowledge, and the academic staff member whose function is connected with linguistics - on the formation of speech skills and abilities in the context of the subject content of the discipline. The new model has a more complex structure of the study, as it involves the interaction of specialists from two different fields and disciplines $^{151}$.

CLIL has an ambivalent focus on special content and contains more than half of the subject content with less linguistic content, i.e. actually given a parity between study, vocabulary, grammar, textual material, on

\footnotetext{
${ }^{147}$ Руднік Ю. В. (2015). Методика предметно-мовного інтегрованого навчання (CLIL). Iнституиійний репозитарій Київського ун-ту ім. Богдана Грінченка. Лютий 1. URL: http://elibrary.kubg.edu.ua/id/eprint/2590.

${ }^{148}$ Коченкова О.М. Возможности профилизации преподавания иностранных языков с помощью применения элементов методики CLIL (интегрирование преподавания иностранного языка и других учебных дисциплин). URL: http://kochenkova.ru/ publ/vozmozhnosti_profilizacii_prepodavanija_inostrannykh_jazykov_s_pomoshhju_primeneni ja_ehlementov_metodiki_clil_integrirovanie_prepodavanija_inostrann/1-1-0-1.

${ }^{149}$ Мовчан Л. Г. (2011). Використання досвіду Швеції у вітчизняній практиці навчання іноземних мов. Гуманізація навчально-виховного процесу. Спец. вип. 7. Ч. 2. С. 217.

${ }^{150}$ Крупченко А. К. Интегрированное обучение иностранному языку и специальности. URL: http://archive.nbuv.gov.ua/portal/Soc_Gum/Vchdpu/ped/2012_101/Krupch.pdf.

${ }^{151}$ Сидоренко Т. В., Рібушкина С. В., Розанова Я. В. (2018). CLIL-практики в Томском политехническом университете: успехи и неудачи. Образование и наука. Том 20, № 8. 2018 / The Education and Science Journal. Vol. 20, № 8. C. 171.
} 
the one hand, and content-thematic component with extrapolation for practical application, on the other hand, and the creation of communication actions to model the relevant situations during the study of a foreign language.

Frequently undergraduates, being in a situation of communication in foreign languages, are unable to show their knowledge in the field of special knowledge and do not have the opportunity to communicate in a professional context. In addition, there are limited access to information resources and a lack of foundation for professional growth. Will some profiling of foreign language teaching allow us to move away from the usual contexts of "My Family"? "Seasons and Weather" and address the communication situations typical of future professional and universal communication of undergraduates. Therefore, a functional approach to teaching a foreign language allows achieving even greater efficiency, taking into account the proposal of a wide general educational space as a learning context ${ }^{152}$.

The use of a foreign language in CLIL education depends on the educational objectives and goals. CLIL brings together a number of theories and approaches used in different educational contexts. There are several terms that describe how to implement CLIL: full language immersion, "language shower", and so on. In defining the basic principles of the CLIL methodological approach in different European countries, four main aspects are identified, covering the cultural and linguistic environment and aimed at solving subject and educational problems. Each of the four aspects is implemented differently and depends on the age of the undergraduate, the socio-linguistic environment, and the degree of immersion in the CLIL methodology ${ }^{153}$.

When revealing the essence of the method, we are faced with the definition of axiological guidelines, which are decisive in achieving the goal of integrative learning. It is not only about the acquisition of

\footnotetext{
${ }^{152}$ Шевченко I. В., Кордюк О.М. (2018). Методика предметно-мовного інтегрованого навчання у сучасній методичній і наукові літературі вітчизняних і закордонних авторів. Молодий вчений. № 4.4(56.4). С. 32.

${ }^{153}$ Шевченко I. В., Кордюк О. М. Переваги використання методики (CLIL) в процесі навчання майбутніх вчителів англійської мови у сучасних ВЗО України. Молодий вчений. № 6(58), червень, 2018. С. 178.
} 
language competencies and simultaneous mastery of knowledge in a particular subject, but a kind of set of educational and developmental guidelines. These include the " $4 \mathrm{C}$ " model, which, in our opinion, considers the CLIL methodology as basic content on a particular topic, which contributes to a comprehensive consideration of a particular problem, issue through language acquisition, communication, and intercultural communication.

So, we are talking about the model " $4 \mathrm{C}$ " - Cognition, Communication, Content, Culture. The direction of "Cognition" involves the formation of perception, learning skills, and abilities. Planning, discussion, use of higher levels of thinking, analysis of learning practice is provided then. "Communication" distinguishes communication itself as a side of language acquisition, and language as a means to master the material. Direction "Content" is aimed at the disclosure of subject content and further understanding, acquisition of knowledge and skills. Mastering new knowledge based on previous experience. The aspect of "Culture" is seen as respect for different cultures, education of multiculturalism, support of the native language and culture, understanding of oneself, and others ${ }^{154}$.

The CLIL methodology in its formation and further implementation in the educational process has identified several models of application of integrative courses. Most researchers are inclined to have three main models of the CLIL implementation methodology itself.

Researcher on integrated learning, Professor K. Coyle identifies three CLIL models. Model C1: multilingual learning. In this case, when teaching different subjects, several foreign languages are used in different years of study. This model of education allows undergraduates to acquire professional knowledge in several languages after completing the entire course. In addition, this model is designed to attract the most focused and talented undergraduates from different countries. Model C2: auxiliary/additional integrated subject and language learning. This model of teaching involves the parallel teaching of subjects. The emphasis is on

\footnotetext{
${ }^{154}$ Берегова О. А., Скляренко А. Б. (2018). Міжнародний досвід імплементації методології CLIL. Матеріали IV Міжнародної науково-практичної конференції «Неперервна освіта нового сторіччя: досягнення та перспективи» (14-21 травня 2018 року, м. Запоріжжя). Випуск № 2(31). URL: https://www.zoippo.zp.ua/pages/el_gurnal/pages/vip31.html.
} 
the development of knowledge and skills for the use of language in order to ensure the mental processes of the highest order. Language teaching is related to special areas, so academic staff members who are specializing in foreign language, who are part of the structural units for teaching specialties, provide external support during the training of specialists. In the process of content and language integrated learning, undergraduates acquire the ability to use a foreign language to work in their specialty. Model C3: subject courses with the inclusion of language support. Specialty training programs are developed in terms of not only the development of professional but also language skills. With this model, teaching is conducted by both academic staff members with a concentration on subject and specialists in the field of language teaching. Even with poor language skills, an undergraduate can receive support throughout the learning process, making it possible to master both the subject and the language in which the subject is taught. Undergraduates with different language levels can study according to this model $^{155}$.

Model C1 is implemented only in higher education institutions of a certain specialization (for example, business and management), and models $\mathrm{C} 2$ and $\mathrm{C} 3$ are the most common. The CLIL method originated in the study of the humanities but is becoming increasingly common in the study of subjects that are abbreviated MINT (mathematics, computer science, science, engineering). These models have also found practical application in higher education institutions abroad, in particular, in the European Union. In Ukraine, the proposed models are used in part, mainly in the secondary education sector, where they are more flexible in the integration of subjects. In higher education institutions CLIL methodology is implemented as an experimental and is not widely used today.

Echoes with the above structure views on CLIL methods of scientists S. John-Georgia and P. Paul, who argue that among the features of the CLIL method can be divided into three mains. 1. The study of a foreign

\footnotetext{
${ }^{155}$ Coyle D. (2007). Content and Language Integrated Learning: towards a connected research agenda for CLIL pedagogies. International Journal of Bilingual Education and Bilingualism. Vol. 10. № 5. P. 543-562.
} 
language integrated into the content of the subject itself, such as science, history, geography. Undergraduates learn a foreign language with the help of the facilitated content of the subject. 2. CLIL has its origins in various socio-linguistic and political contexts and applies to any language, age, and level of education: from pre-school, primary to higher, vocational training. In this sense, CLIL is in line with all European educational programs for all citizens, where multilingualism and multiculturalism are considered to promote integration, understanding, and mobility among Europeans. 3. CLIL is an approach that involves the development of social, cultural, cognitive, linguistic, academic, and other learning skills, which in turn contribute to the achievement in the field of learning, both the subject and language ${ }^{156}$.

It is necessary to pay attention to four factors of the CLIL methodology, which have some similarities with other previous approaches to learning a foreign language. The first feature is the naturalistic and implicit style of CLIL teaching methods. According to Jarvinen, the CLIL's naturalistic and implicit learning style should be understood as an increase in communication opportunities due to a greater focus on the input that the undergraduate receives from the external environment. A large amount of information provides better learning outcomes. The second feature of CLIL is the style of cooperative learning. During the joint study, undergraduates are usually divided into small groups to complete tasks through teamwork. The cooperative learning style is effective because it allows you to get rid of anxiety in the learning process, stimulate undergraduate`s motivation, and promote interaction between them. Undergraduate`s autonomy, created as part of a cooperative teaching method, and interaction with a team member helps to improve their communication skills while learning a language. The third feature of CLIL is authenticity, which allows undergraduates to develop the ability to solve communication problems in real life. During authentically oriented learning, materials are selected based on the real language environment. The fourth feature of CLIL is flexibility. The CLIL methodology can be used for

\footnotetext{
${ }^{156}$ Ioannou-Georgiou S., Pavlou P. Assessing Young Learners. Oxford University Press. P. 18.
} 
implementation in different curricula with different content of subject research $^{157}$.

D. Graddol believes that the use of CLIL will allow undergraduates, in the first place, to significantly increase the level of foreign language proficiency. It also considers the use of a foreign language in the learning process, in particular English, as a basic skill that allows undergraduates to develop communication skills. Such an understanding of CLIL is important in the context of changes in education and society as a whole, due to the rapid development of Internet technologies and the process of globalization $^{158}$.

The basic principles of CLIL are easy to understand and easy to implement in the learning process. It is always interesting for both participants in the learning process in higher education: academic staff members and undergraduates: CLIL is primarily learning general knowledge, not multilingualism, so the latter is only an additional function of learning takes place, based on the basic 4 " $\mathrm{C}$ ". All these components are in constant connection with each other: it requires building a safe psychological climate in the classroom; implies the use of only one (foreign) language, the same academic staff member and audience; for a better understanding of the material, the academic staff member can connect facial expressions, gestures, pictures, presentation sound, etc. In addition, CLIL allows undergraduates to communicate more effectively with each other using a foreign language; expands intercultural knowledge; develops communication skills in a foreign language in real conditions; develops thinking and opens creative potential; increases undergraduates' motivation and self-confidence; trains all language skills and develops speech skills; arouses interest in the use of a foreign language in professional fields; does not require additional hours of study. As a result, a foreign language acts as an effective way to establish interdisciplinary links within the curriculum,

\footnotetext{
${ }^{157}$ Крашенникова А. Е. К вопросу об использовании предметно-языкового интегрированного обучения CLIL. URL: http://www.rusnauka.com/3_ANR_2013/ Pedagogica/5_126661.do.htm.

${ }^{158}$ Graddol D. (2006). English Next, British Council Publications. URL: http://www.britishcouncil.org/learning-research-englishnext.htm.
} 
as well as a language of intercultural communication, because the study of a foreign language takes place in a foreign professional context ${ }^{159}$.

In Using the CLIL methodology reveals an integrative resource of a foreign language and has a positive impact on undergraduate's motivation, values of the chosen profession, readiness for intercultural communication, provide immersion in the language environment. Motivation to learn a foreign language increases when speech activity is aimed at solving real problems. If an undergraduate is interested in studying certain information, he or she will have an additional incentive to learn the material, to be an active participant in the discussion, to express his opinion. Integrative learning is an effective model of activating intellectual activity and developing learning techniques, which opens the possibility of combining multidisciplinary socio-humanitarian knowledge ${ }^{160}$.

Thus, in general, within the CLIL methodology, the undergraduate passes through a fairly large amount of language material, which is a full immersion in the natural language environment. It should also be noted that working on various topics allows you to learn specific terms, defined language structures, which helps to replenish the vocabulary of subject terminology and prepares the undergraduate for further study and application of knowledge and skills. This technique contributes to the formation of a comprehensively developed personality by simultaneously mastering knowledge of a foreign language, knowledge of a particular discipline, develops communication skills in the process of communication and learning.

It should be noted that the implementation of content and language learning models in higher education institutions in Ukraine faces certain difficulties: academic staff members who are specializing in a foreign language need meaningful support for the content of humanities and, conversely, academic staff members who are focused

\footnotetext{
${ }^{159}$ Волкова Г. К. (2018). CLIL-технології у навчанні іноземної мови як засіб формування професійних компетенцій фармацевтів. Новини науки XXI століття, ХХIV Міжнародна науково-практична інтернет-конференція. м. Віннищя, 23 листопада 2018 . Вінниця. Ч. 5. C. $25-30$.

${ }^{160}$ Нечипоренко М. А. (2017). Інтегративний ресурс іноземної мови в контексті проблеми професійно-особистісного саморозвитку майбутнього учителя. Science and Education a New Dimension. Pedagogy and Psychology, V (57), Issue: 129. P. 27.
} 
on subject of the social sciences do not always have a sufficient level of foreign language proficiency, there is a difficulty in the distribution of hours due to the need to combine the teaching of disciplines at a certain stage of the educational process. Also, the proposed models of CLIL-methodology of the most optimal for higher education institutions of Ukraine at the present stage will be the first model, which involves the study of linguistic features of a special subject context. However, this approach somewhat facilitates the study of the subject of the socio-humanitarian cycle, but, at the same time, deepens the level of mastery of a foreign language.

The interdisciplinary approach becomes the foundation for the development of intercultural communication and can be a factor in influencing society in terms of forming a tolerant attitude towards other cultures, creating intercultural discourse, understanding the separateness of one's own culture and mentality. It should be noted that establishing a high level of intercultural communication will help to overcome ethnic stereotypes and make it impossible or have a preventive role in preventing ethnic conflicts. Of course, knowledge of a foreign language plays a significant role in creating intercultural communication.

Given the above, an important component of multilingual education is also the formation of intercultural competence. It is not enough to master verbal communication, it is necessary to be aware of the peculiarities of different cultures, cultural interaction between their representatives, which provides an opportunity to realize their belonging to a particular ethnic group, effectively act as a mediator between their own and other cultures, perceive intercultural interaction as a necessary condition of self-realization ${ }^{161}$.

Involvement in the educational process of content and language integrated learning acquires special significance. The CLIL methodology, based on an integrated interdisciplinary approach, promotes the acquisition of intercultural knowledge, the development of creative thinking of undergraduates, the formation of both professional

\footnotetext{
${ }^{161}$ Питій Т., Берегова О. Моделювання освітнього середовища нової якості на засадах багатомовної освіти: запорізький експеримент. URL: http://www.baltijapublishing.lv/ download/pedpsy-science/40.pdf.
} 
and general language competencies. The use of CLIL in a non-language institution of higher education contributes to the formation of a competent, competitive, highly qualified specialist capable of effective communication in a professional environment ${ }^{162}$.

At one time, the understanding that culture is interconnected with various forms of behavior of individuals and groups, with values and their hierarchical configurations in the social consciousness of social actors, necessitated the sociological support of social mechanisms that control human behavior primarily through identification and selfidentification and certain communities and their inherent regulatory systems. Today we observe such a significant deepening into the sociopsychological layers and planes of mental and cultural conditions of the behavior of groups and individuals in parallel with the transformation of the social structure of society, that it seems appropriate interdisciplinary methodological support to study the conflict potential of cultural differences ${ }^{163}$.

Only people who are aware of the consequences of neglecting the multicultural nature of the modern world can find a way of understanding. Thus, it is quite possible to solve problems both at the level of education and upbringing and at the political level. The modern European strategy for the development of interculturalism in no way insists on leveling cultural differences in the common life of different ethnic groups. Interculturalism substantiates approaches to the development of interaction (Inter $=$ within and between) cultural groups and communities based on purposeful assistance at every opportunity to unite people of different cultural traditions, meaningful interactions and search for forms and means of openness, interpenetration, and friendship of cultures ${ }^{164}$.

\footnotetext{
${ }^{162}$ Свтушенко Н. (2019). Особливості використання методики предметно-мовного інтегрованого навчання (CLIL) при підготовці студентів-філологів педагогічних вузів. Актуальні питання гуманітарних наук. Вип. 26. Том 1. С. 81.

${ }^{163}$ Глєбова Н. І. (2015). Міждисциплінарний дискурс дослідження потенціалу сучасних культурних практик. Versus, № 2(6). С. 27.

${ }^{164}$ Афанасьєва Л., Олексенко Р. (2018). Актичні інтеркультурні практики як індикатор взаємодії культурних груп і спільнот поліетнічного міста. Вісник Львівського університету. Серія : Філософсько-політологічні студї. Випуск 18. С. 45.
} 
This approach promotes intercultural communication and provides opportunities for a comprehensive examination of the specifics of the coexistence of cultures and finding differences in the forms of communication between cultures, especially in multinational communities. The integration and intercultural approach identify ways to implement the principle of multiculturalism, which shapes the strategies and practices of intercultural content and communications of modern Ukrainian society. Of course, it is diversity, as the main characteristic of a multicultural society, that becomes the main subject of integrative consideration and study. At the same time, this approach creates additional learning challenges for both academic staff members and undergraduates given the wide range of content. In our opinion, the implementation of integrated learning will allow reaching the level of critical and problematic approach to understanding intercultural interaction and the acquisition of knowledge and competencies of undergraduates for quality communication in the foreign ethnic and foreign language environment. This creates a basis for the simultaneous process of joining the community, interpenetration, and preservation of their ethnic identity, separateness, i.e. being in a position "between cultures". Knowledge of "non-ethnic" content combined with mastering a foreign language becomes a solid foundation for understanding and delving into these processes, moreover, can lead to changes in the axiological guidelines of both the individual and the social group and possibly society as a whole.

Involving interdisciplinary links and studying a range of humanities in a foreign language will best implement the idea of intercultural communication. The cultural component in the context of content and language integration means awareness and emphasis on oneself and "others", and mastering the knowledge of intercultural discourse will promote cultural adaptation and intercultural communication. The social needs of the modern scientific and pedagogical worker in the duality "academic staff member-undergraduate" become relevant and create a process of finding ways to achieve productivity in the organization of remote teaching. In this regard, it would be appropriate to use the developments of narratives of public sociology, as well as the involvement of humanitarian content as a basis for undergraduates' 
research work and highlighting thematic areas of foreign language learning based on simultaneous learning of history, sociology, philosophy, and others. It will be appropriate to use authentic materials, i.e. developed by native speakers. In general, the humanitarian component becomes a wide field of integrative study of a foreign language using the CLIL methodology and, at the same time, serves as a guarantee of the formation of a quality level of intercultural communication.

\section{Advantages of using the methodology (CLIL) and features of use in teaching}

The methodology of content and language integrated learning and the development of certain methods and techniques for the quality implementation of CLIL technology also need attention and development.

The CLIL methodology also requires a new approach to the organization and conduct of classes. Academic staff members should actively use various forms of presentation of educational material, the organization of the educational process, which is focused on individual and creative activities of undergraduates. The process of studying the main profile disciplines will arouse the greater interest of undergraduates and will be much more effective if it is carried out in the context of the activity and communicative approach inherent in foreign language classes.Technology is an innovative approach to teaching foreign languages in higher education, which allows solving not only the problem of professional mobility of future professionals but also significantly increase undergraduates' motivation to learn a foreign language, to form skills to consciously and freely use a foreign language in professional communication; expand undergraduates' horizons, knowledge, and acceptance of other cultures and values; to form and improve linguistic and communicative competencies through the study of a foreign language, to overcome the language barrier for both undergraduates and academic staff members ${ }^{165}$.

\footnotetext{
165 Денисенко I. І., Тарасюк А. М. (2019). Іноземна мова як інструмент формування професійної мобільності студентів в умовах євроінтеграції. Науковий часопис НПУ імені М. П. Драгоманова. Серія 5. Педагогічні науки: реалї та перспективи. Вип. 70. С. 84.
} 
To create a CLIL lesson, there are certain requirements for the selection of educational material and forms of work: the complexity of the material is slightly below the current level of knowledge in this subject in the native language; texts should be provided with a sufficient number of tasks for understanding and mastering the material; tasks for the text should be built with an emphasis on the subject content, to involve undergraduates in the process of understanding, checking, discussing the main idea of the text on the taxonomy of B. Bloom; tasks should show the features of linguistic forms, practice skills in their creation, use; use different types of verification and evaluation (including mutual control); tasks should stimulate the independent and creative activity of undergraduates, communicative tasks for oral and written communication in a foreign language ${ }^{166}$.

In teaching socio-pedagogical disciplines, it is advisable to use "language shower", one of the CLIL methods, the essence of which is to memorize certain definitions. Exercises can take 2-5 minutes but should be regular. Working with different topics allows you to study specific terms, certain language structures, which helps to replenish the undergraduate`s vocabulary with subject terminology and prepares him for further study and application of acquired knowledge and skills. When planning sociolinguistic training in senior courses, it is assumed that undergraduates have the basic concepts of social pedagogy and social work (such as social assistance, social support, social protection, social security, vulnerable groups, patronage, social support, etc.), familiar with translation definitions and therefore ready to work with professional literature and documentation in a foreign language. Learning a foreign language and a non-language subject is both an additional means to achieve educational goals and has positive aspects for both learning a foreign language and a non-language subject ${ }^{167}$.

Knowledge of a foreign language is through subjects that are professionally necessary and interesting for undergraduates. The essence

\footnotetext{
${ }^{166}$ Marsh, D., Mehisto, P., Wolff, D., Jesús, M., Frigols, M. European Frame-work for CLIL Teacher Education. URL: http://encuentrojournal.org/textos/9.\%20CLILFramework.pdf.

${ }^{167}$ Гладиш М. О. (2017). Викладання соціально-педагогічних дисциплін за методикою інтегративного навчання (CLIL). Вісник Запорізького наиіонального університету, № 2(29). C. 48.
} 
of the profession, which is systematically represented through a foreign language, encourages action, and becomes the main reference point in choosing the purpose of educational activities. Such integrated activities depend on how successful the cooperation of an academic staff member who focuses on a foreign language and an academic staff member who focuses on a subject will be to create a foreign language learning environment for the use of its properties in the process of teaching undergraduates the profession and foreign language. training of future specialists by means of CLIL becomes significant and should take place in such a context in modern higher education ${ }^{168}$.

It should be noted that the use of a communicative approach in the classroom stimulates undergraduates to develop speech, and competency - to use professional terminology in their speech and the structure of the lesson (PPP, ESA, Patchwork) encourages undergraduates to rely on their life and professional experience using the method of specific situations for each structure (creating a problem situation based on real-life facts), illustrative learning situations; applied situations, in which a specific situation is described, it is proposed to find ways out of it and situations that teach to carry out analysis and evaluation.

Criteria for selecting such learning and speech situations should be: motivation and planned reflexivity of the undergraduate in a situation of "immersion"; receiving/transmitting the necessary subject information to the content of social and humanitarian disciplines; obligatory involvement of all communicators in the learning-speech situation, i.e. all participants of the situation-task must speak; clearly formulated instructions on the role of each communicator; taking into account the age characteristics of undergraduates.

In order for the implementation of all these elements to be rational, the academic staff member must make sure that there are ways to support undergraduates in the classroom: at the word level (word banks, glossaries, target language, dictionaries, visuals, realities, labels, most

\footnotetext{
${ }^{168}$ Александров В. М., Александрова О. Ф. (2019). Інтегроване навчання предмета й іноземної мови у вищій школі. Integrated learning of subject and foreign language at high school. Інноваційна педагогіка. Випуск 13. Т. 2. С. 58.
} 
used words); at the sentence level (beginning of the sentence, beginning of the question, base tables, sentences with missing words); at the text level (diagrams, videos, text content prediction, sample texts, language constructions $)^{169}$.

Designing tasks for the disciplines of the humanities can consist of the following training exercises: sociology - compiling questionnaires, questionnaires in two (or more) languages, modeling focus groups in a foreign language, planning, and development of events, development of promotional information; history - a creation of historical business cards of the country, drawing up of maps-characteristics of the mentality of a certain ethnic group, the formation of tourist local lore routes, programming of electronic simulators on thematic directions, chronological, terminological. It is necessary to emphasize the wide opportunities of undergraduates to perform tasks using information technology: videos, presentations, work with electronic media sources, making various cards, diagrams, and so on. in electronic form.

An important component of integration training is also the professional orientation and study of a foreign language in the specialty.

The peculiarity of the foreign language component of the undergraduate training program in terms of integration into professional activities is the introduction of special vocabulary, consideration of the features of reading and writing scientific texts, solving educational problems, discussing professional issues. Integrative learning is conducted in the context of active professional communication on topics devoted to undergraduate's research. The integration of the foreign language component into the professional activity of the undergraduate contributes to the activation of latent lexical knowledge and motivation for further improvement. But most often the vocabulary obtained in foreign language courses is unclaimed by undergraduates in their professional activities due to the maladaptation and incoherence of the courses with professional competence. To solve this problem, it is necessary to integrate scientific knowledge in the professional field from

\footnotetext{
${ }^{169}$ Крашенникова А. Е. К вопросу об использовании предметно-языкового интегрированного обучения CLIL. URL: http://www.rusnauka.com/3_ANR_2013/ Pedagogica/5_126661.do.htm.
} 
a foreign language component of the course by introducing into the learning process foreign language vocabulary and professionally relevant information in direct connection with public knowledge in professional activities $^{170}$.

It is necessary to involve the use of integrated learning and coordination between classes in disciplines of specialization and practical classes on methods of teaching a foreign language, where the acquired pedagogical and special knowledge must be adapted within the specified limits of specific foreign language communicative competence. It should be important for higher education to take into account the content components of pedagogical and psychological nature, which are necessary for the integration of subject and language learning in the methodological, pedagogical, and psychological sciences, taking into account the conditions and requirements of the remote teaching.

The advantages of the CLIL method include the fact that the focus is on the long-term prospect of working with a foreign language, as a result - a high level of mastery of a foreign language increases the interest in learning it. In recent years, it has been clearly stated that bilingual subject teaching is based on the principles of didactics of teaching these subjects. Mastering the content of these subjects is no less important than mastering a foreign language. Empirical studies show that - humanitarian cycle.

\section{CONCLUSIONS}

Therefore, in the field of higher education, interdisciplinary links play an important role in the integration process. One of the forms of their implementation is the methodology of content and language integrated learning - pedagogical technology CLIL, which has proven itself as a basis for quality implementation of the purpose of interdisciplinary learning in foreign languages and subjects of the humanities. A promising direction for the development of this issue is the development of methods and techniques for implementing the CLIL methodology.

\footnotetext{
${ }^{170}$ Ніканорова Л. І. (2019). Застосування інтегрованого підходу до навчання іноземній мові. Методичні проблеми. 13th International youth conference. "Perspectives of science and education", 22 November 2019. New York. C. 303-312.
} 
In our opinion, it is necessary to pay considerable attention to exercises on ranking information, to develop a strategy of vocabulary acquisition through the construction of meaningful skeletons of the topic with the obligatory task of choosing the situation of knowledge acquisition, to use role-playing games and mini-trainings, and for undergraduates, to use electronic didactic materials such as cards with missing words, with the need to fill in the missing elements in the scheme-bush, etc., as well as to encourage the compilation of intelligence maps.

Clearly, we note the need to use modern information technology and implement their application for both tasks and their implementation through the following tools: compiling software to protect a particular topic - an electronic exercise simulator, filling an electronic circuit with missing elements, and more. An integrative approach should be followed when creating such tasks and didactic electronic material.

In the process of implementing the semantic component of reproducing a certain topic in vocabulary, it is important to think about tasks in related humanities, introducing such information, not at the stage of homework (usually a undergraduate's research work), but when considering a new topic. This will contribute to the actualization of knowledge and high motivation to learn a foreign language with a combination of the study of history, sociology, philosophy, and more. Thus, the implementation of modern pedagogical technology of segmentation of disciplines with their subsequent assemblhey into a mosaic with the use of a problem-based approach in the study of social sciences and humanities will also be achieved.

By the way, we note that among modern youth there is an obstacle during the study of problem-based learning to identify cause-and-effect relationships of socio-political, historical phenomena, there are also difficulties in solving problems using critical thinking skills or tasks in a limited time. Interestingly, the stated problem has several dimensions. On the one hand, undergraduates really lack knowledge of the sociohumanitarian cycle of disciplines and a relatively narrow outlook. On the other hand, there is the problem of implementing knowledge in a foreign language environment. There is also psychological tension during the performance of communicative tasks, and even under the conditions of 
using certain role-playing games, when it is necessary to demonstrate both knowledge of certain vocabulary and skills of working in pairs, groups, and other.

It is especially difficult to implement such tasks while remote teaching. Some academic staff members and undergraduates are set up to perform electronic tasks and communication through various electronic systems and platforms, but just as correspondence, i.e. just send works. This type of activity significantly narrows the pedagogical influence and reduces the quality of knowledge acquisition. On the other hand, academic staff members make extensive use of online platforms for faceto-face classes (computer-assisted). It is during such classes that there are difficulties in performing role tasks, games, attempts to simulate dialogue and communication situations, to demonstrate the skills of immersion in the cultural layer of the "other" community, and so on. Thus, difficulties arise in the processes of generalization and evaluation, as well as reflection. The development of undergraduates' competencies is inhibited, according to the terminology of the conceptual apparatus in Bloom's taxonomy, at the levels of "knowledge", "understanding" and "use" and is not transformed into rising to the level of "analysis", "synthesis" and "evaluation".

Thus, undergraduates' cognitive processes do not develop intensively enough, which prevents the formation of long-term and quality knowledge. It is for the implementation of such exercises that integration, interdisciplinary knowledge, cognitive skills, and an appropriate system of implementation of the methods and techniques proposed by the academic staff member are needed. The academic staff member should carefully consider additional tasks: cards with explanations of tasks with the importance of updating certain actions during the exercise, successfully compose tasks both in terms of mastering the material for learning a foreign language and prescribe certain actions to perform exercises in the form of diagrams, logical chains, construction of dialogues-examples.

Psychological factors have a significant component, respectively, the academic staff member should work in this direction and further explain both the mechanism of tasks and the need to use this type of work and focus on further application of acquired knowledge in practice. The tasks 
of CLIL methodology should contain basic exercises, terminology, and elements of information and communication technologies, it should be emphasized that the involvement of such a resource of pedagogical developments corresponds to the provision of quality of remote teaching.

In our opinion, it is the CLIL technique that has an undeniable advantage in the process of learning a foreign language in order to achieve a solution to this range of problems, helps to systematize the acquired knowledge, integrate into further professional activities, and be realized in intercultural contacts.

\section{SUMMARY}

In higher education, interdisciplinary links play an important role in integration processes. One of the forms of their implementation is the methodology of content and language integrated learning, which has recently found application in higher education institutions. The aim of the research was to clarify the place of Content and Language Integrated Learning as an interdisciplinary phenomenon in the higher education system. The structure of CLIL-methodology is considered, the advantages and disadvantages of application are analyzed, the necessity of creation of "pedagogical tandems" of the academic staff members who are focused on language, on the one hand, the academic staff members who are focused on subject, on the other is singled out. It is emphasized that the key characteristic of CLIL-learning is the cognitive component. The proposed intelligence also indicates a significant role in the application of this technique begins to play undergraduates who are involved in the processes of task formation, in particular through a variety of information technologies. This becomes especially relevant when using remote teaching, during which a significant part of the learning material undergraduates master themselves. At the same time, the best acquaintance of undergraduates with modern information technologies creates favorable conditions for high-quality performance of tasks by means of the CLIL technique. The peculiarities of the application of the CLIL-method in the study of humanities are also highlighted, and it is emphasized that it is during the acquisition of knowledge in this field that the application of this pedagogical technology began. The paper emphasizes that the combination of 
learning a foreign language and the humanities becomes a guarantee of overcoming socio-psychological barriers in the process of education and training, as well as during the further socialization of the undergraduate and in intercultural contacts. Further development of the topic lies in the need to develop the theory of CLIL learning and requires additional research on the interaction of language and culture, as well as approaches to the use of information and communication technologies in the application of CLIL.

\section{REFERENCES}

1. Александров В. М., Александрова О. Ф. (2019). Інтегроване навчання предмета й іноземної мови у вищій школі. Integrated learning of subject and foreign language at high school. Інноваційна педагогіка. Випуск 13. Т. 2. С. 57-60.

2. Афанасьєва Л., Олексенко Р. (2018). Актичні інтеркультурні практики як індикатор взаємодії культурних груп і спільнот поліетнічного міста. Вісник Львівського університету. Серія : Філософсько-політологічні студіі. Випуск 18. С. 40-47.

3. Берегова О. А., Скляренко А. Б. (2018). Міжнародний досвід імплементації методології CLIL. Матеріали IV Міжнародної науковопрактичної конференції «Неперервна освіта нового сторіччя: досягнення та перспективи» (14-21 травня 2018 року, м. Запоріжжя). Випуск № 2(31). URL: https://www.zoippo.zp.ua/pages/el_gurnal/pages/ vip31.html.

4. Волкова Г. К. (2018). CLIL-технології у навчанні іноземної мови як засіб формування професійних компетенцій фармацевтів. Новини науки XXI століття, ХXIV Міжнародна науково-практична інтернетконференція. м. Вінниця, 23 листопада 2018 р. Вінниця, 2018. Ч. 5. C. 25-30.

5. Денисенко I. І., Тарасюк А. М. (2019). Іноземна мова як інструмент формування професійної мобільності студентів в умовах євроінтеграції. Науковий часопис НПУ імені М. П. Драгоманова. Серія 5. Педагогічні науки: реалії та перспективи. Вип. 70. С. 80-84.

6. Гладиш М. О. (2017). Викладання соціально-педагогічних дисциплін за методикою інтегративного навчання (CLIL). Вісник Запорізького національного університету, № 2(29). С. 45-48. 
7. Глєбова Н. І. (2015). Міждисциплінарний дискурс дослідження потенціалу сучасних культурних практик. Versus № 2(6). С. 25-31.

8. Свтушенко Н. (2019). Особливості використання методики предметно-мовного інтегрованого навчання (CLIL) при підготовці студентів-філологів педагогічних вузів. Актуальні питання гуманітарних наук. Вип. 26. Том 1. С. 77-82.

9. Коченкова О. М. Возможности профилизации преподавания иностранных языков с помощью применения элементов методики CLIL (интегрирование преподавания иностранного языка и других учебных дисциплин). URL: http://kochenkova.ru/publ/vozmozhnosti_profilizacii_ prepodavanija_inostrannykh_jazykov_s_pomoshhju_primenenija_ehlemento v_metodiki_clil_integrirovanie_prepodavanija_inostrann/1-1-0-1.

10. Крашенникова А. Е. К вопросу об использовании предметноязыкового интегрированного обучения CLIL. URL: http://www.rusnauka.com/3_ANR_2013/Pedagogica/5_126661.do.htm.

11. Крупченко А. К. Интегрированное обучение иностранному языку и специальности. URL: http://archive.nbuv.gov.ua/portal/Soc_Gum/ Vchdpu/ped/2012_101/Krupch.pdf.

12. Мовчан Л. Г. (2011). Використання досвіду Швеції у вітчизняній практиці навчання іноземних мов. Гуманізація навчальновиховного процесу. Спец. вип. 7. Ч. 2. С. 214-220.

13. Нечипоренко М. А. (2017). Інтегративний ресурс іноземної мови в контексті проблеми професійно-особистісного саморозвитку майбутнього учителя. Science and Education a New Dimension. Pedagogy and Psychology, V (57), Issue: 129. P. 25-28.

14. Ніканорова Л. І. (2019). Застосування інтегрованого підходу до навчання іноземній мові. Методичні проблеми. 13th International youth conference. "Perspectives of science and education", 22 November 2019. New York. C. 303-312.

15. Питій Т., Берегова О. Моделювання освітнього середовища нової якості на засадах багатомовної освіти: запорізький експеримент. URL: http://www.baltijapublishing.lv/download/pedpsy-science/40.pdf.

16. Руднік Ю. В. (2015). Методика предметно-мовного інтегрованого навчання (CLIL). Інституиійний репозитарій Київського ун-ту ім. Богдана Грінченка. Лютий 19. URL: http://elibrary.kubg.edu.ua/ id/eprint/2590.

17. Сидоренко Т. В., Рібушкина С. В., Розанова Я. В. (2018). CLILпрактики в Томском политехническом университете: успехи и неудачи. 
Образование и наука. Том 20, № 8. 2018 / The Education and Science Journal. Vol. 20, № 8. C. 164-187.

18. Шевченко І. В., Кордюк О. М. (2018). Методика предметномовного інтегрованого навчання у сучасній методичній і наукові літературі вітчизняних і закордонних авторів. Молодий вчений. № 4.4(56.4). С. 31-34.

19. Шевченко І. В., Кордюк О. М. (2018). Переваги використання методики (CLIL) в процесі навчання майбутніх вчителів англійської мови у сучасних ВЗО України. Молодий вчений. № 6(58). С. 177-180.

20. Coyle D. (2007). Content and Language Integrated Learning: towards a connected research agenda for CLIL pedagogies. International Journal of Bilingual Education and Bilingualism. Vol. 10. № 5. P. 543-562.

21. Graddol D. (2006). English Next, British Council Publications. URL: http://www.britishcouncil.org/learning-research-englishnext.htm.

22. Ioannou-Georgiou S., Pavlou P. Assessing Young Learners. Oxford University Press, $192 \mathrm{p}$.

23. Marsh, D., Mehisto, P., Wolff, D., Jesús, M., Frigols, M. European Frame-work for CLIL Teacher Education. URL:: http://encuentrojournal.org/textos/9.\%20CLILFramework.pdf. 